\title{
The Efektiveness of Think Pair Share Model to Impoving Critical Thinking for Student of Elementary School Education Nusa Cendana Univercity
}

\author{
Fembriani, Taty R Koroh \\ Universitas Nusa Cendana \\ fembriani@staff.undana.ac.id
}

\section{Article History}

accepted 24/09/2019

approved 01/10/2019

published 01/12/2019

\begin{abstract}
Learning of Primary School Teacher Education (PGSD) needs to improving with' critical thinking skills. Critical thinking for student in integrated learning, the basis of this research. In this case integrated learning has a low critical thinking ability value. The research will be conducted in PGSD Nusa Cendana Univercity in 4th semester using the think pair share model. The purpose of this study to determine effectiveness of learning includ differences in critical thinking skills and increasing critical thinking skills. The results of this study 1) the ability to think critically for students after learning using the think pair share model that the significance results 0,000 $<0.005$ that $\mathrm{Ho}$ is rejected and $\mathrm{Ha}$ is accepted means that there are differences in students' critical thinking skills in the control and experimental class. 2) there is an increase in students' critical thinking skills with the acquisition of N-Gain value of 0.65 which is in the range of $0.70>$ $g>0.30$ in the medium criteria. It can be concluded that think pair share model can improve critical thinking skills of PGSD Nusa Cendana Univercity.
\end{abstract}

Keywords: Efektivenees, Think Pair Share, Critical Thinking

\begin{abstract}
Abstrak
Pembelajaran di kampus Pendidikan Guru Sekolah Dasar (PGSD) perlu diperbaiki terkait dengan kemampuan berpikir kritis mahasiswa. Kemampuan berpikir kritis mahasiswa pada matakuliah pembelajaran terpadu menjadi dasar penelitian ini. Dalam hal ini pembelajaran terpadu memiliki nilai kemampuan berpikir kritis yang rendah. Penelitian akan dilaksanakan di Kampus PGSD Universitas Nusa Cendana pada semester 4 dengan menggunakan model think pair share. Tujuan penelitian ini untuk mengetahui efektivitas dalam pembelajaran meliputi perbedaan kemampuan berpikir kritis dan peningkatan kemampuan berpikir kritis. Hasil penelitian ini 1) kemampuan berpikir kritis pada mahasiswa setelah dilaksanakan pembelajaran menggunakan model think pair share bahwa hasil signifikansi $0,000<0,005$ bahwa Ho ditolak dan Ha diterima artinya ada perbedaan kemampuan berpikir kritis mahasiswa pada kelas kontrol dan eksperimen. 2) terdapat peningkatan kemampuan berpikir kritis mahasiswa dengan perolehan nilai $\mathrm{N}$-Gain sebesar 0,65 yang berada pada rentang $0,70>\mathrm{g}>0,30$ pada kriteria sedang.Dapat disimpulkan model pembelajaran think pair share dapat meningkatkan kemampuan berpikir kritis mahasiswa PGSD Universitas Nusa Cendana.
\end{abstract}

Kata kunci: Efektivitas, Think Pair Share, kemampuan berpikir kritis.

Social, Humanities, and Education Studies (SHEs): Conference Series https://jurnal.uns.ac.id/shes

p-ISSN 2620-9284

e-ISSN 2620-9292 


\section{PENDAHULUAN}

Pendidikan guru sekolah dasar (PGSD) Universitas Nusa Cendana menjadi tempat belajar calon guru SD untuk menjadi guru inovatif. Kemampuan dasar seorang guru dapat dinilai dari cara guru mengimplemntasikan ilmu yang dimiliki untuk proses belajar mengajar yang edukatif.. Demikian pula menjadi guru SD agar bisa mengimplementasikan kamampuannya secara sempurna harus memilki 4 komptensi guru.

Guru yang berkompeten memiliki 4 kompetensi guru mulai dari kompetensi profesional, pedagodik, sosial, sampai pada kepribadian. Keberagaman di dalam kelas membutuhkan keterampilan guru untuk membuat desain pembelajaran sebagai kemampuan pedagogik guru. Seorang guru juga berkewajiban memiliki kemampuan mengelola proses belajar mengajar serta kemampuan mengelola kelas sampai penggunaan media belajar sebagai kompetensi profesional yang harus dimiliki. Selain itu guru harus menunjukan kepribadian yang baik sebagai teladan untuk peserta didiknya. Kompetensi guru tersebut akan berjalan dengan baik jika seorang guru memiliki kemampuan berpikir kritis.

Berpikir kritis sebagai kemapuan disiplin intelektual proses konseptualisasi aktif dan terampil, menerapkan, menganalisis, mensintesis, dan/atau mengevaluasi informasi yang dikumpulkan dari, atau dihasilkan oleh, pengamatan, pengalaman, refleksi, penalaran, atau komunikasi, sebagai apanduan untuk keyakinan dan tindakan (Styron, 2014).

Mahasiswa sebagai seoarng calon guru diharapkan dapat mengembangkan 4 keterampilan guru tersebut dengan didukung kemampuan berpikir kritisnya. Karena kemampuan berpikir kritis akan mendukung calon guru memahami apa yang harus dilakukan sebagai seorang guru teladan. Dalam perkuliahan di Pendidikan Guru Sekolah Dasar memerlukan pengembangan kemampuan berpikir kritis. Dalam hal ini pada mata kuliah pembelajaran terpadu kemampuan berpikir kritis mahasiswa perlu ditingkatkan. Rendahnya kemampuan berpikir kritis dilihat diantaranya hasil belajar dan keaktifan mahasiswa dalam kelas.

Pada mata kuliah pembelajaran terpadu mahasiswa dituntut untuk mempelajari dan mampu menyusun perangkat pembelajaran dengan K13. Belajar tentang jenisjenis pembelajaran terpadu sampai pada strategi yang harus digunakan dalam membelajarkan peserta didik. Dalam hal ini mahasiswa belum mampu mengembangkan kemampuan berpikir kritisnya untuk dapat menyusun perngkat pembelajaran yang sesuai. Hal ini dilihat dari hasil peniliain kemampuan berpikir kritis berdasarkan indikator yang telah ditetapkan.

Nilai kemampuan berpikir kritis mahasiswa PGSD Undana sangat rendah. Hal ini dibuktikan dengan observasi yang peneliti lakukan di kelas $E$ semeter 4 tahun akademik 2018/2019 bahwa nilai kemampuan berpikir kritis rendah. Hal ini diukur dengan pemberian soal yang mengandung indikator berpikir kritis mahasiswa. Dari 49 mahasiswa yang memenuhi kelulusan dengan nilai di atas 60 hanya 10 mahasiswa. Hal itu berarti lebih dari $80 \%$ siswa tidak memenuhi batas kelulusan.

Penelitian ini menggunakan penelitian eksperimen untuk menerapkan think pair share pada mahasiswa PGSD Universitas Nusa Cendana. Mahasiswa PGSD pada kelas $\mathrm{D}$ adalah mahasiswa yang dalam jumlah besar, akan tetap keatifan mahasiswa dalam kelas masih kurang. Mahasiswa kurang menggali dan mengasah kemampuan berpikirnya sehingga mereka tidak dapat mencari jalan keluar dari masalah yang berikan oleh dosen. Mahasiswa juga masih cenderung individualisme belum mau untuk berbagi dengan teman tentang materi yang mereka ketahui. Tentu saja hal ini berpengaruh pada hasil belajar mahasiswa. Rendahnya hasil belajar mahasiswa juga cenderung disebabkan karena rendahnya kemampuan berpikir kritis mahasiswa.

Model think pair share ini diyakini peneliti akan mampu mengembangkan kemampuan berpikir kritis mahasiswa yang dapat juga berakibat meningkatnya hasil 
belajar mahasiswa. Untuk media mahasiswa menggembangkan kompetensi sebagai calon guru tersebut salah satu hal yang penting yaitu kemampuan bepikir kritis. Guru yang hebat adalah guru yang mampu mengembangkan kemampuan berpikir kritis. Kemampuan berpikir kritis adalah Kemampuan berpikir kritis merupakan kemampuan berpikir kompleks. Hal ini didukung pendapat Snyder \& Snyder (2008) bahwa critical thinking merupakan proses intelektual disiplin aktif untuk menerapkan, menganalisis, mensintesis, dan mengevaluasi informasi yang dikumpulkan sebagai panduan untuk keyakinan dan tindakan. Melalui kemampuan berpikir kritis, siswa lebih mudah memahami konsep dan peka terhadap masalah. Mata kuliah pembelajaran terpadu perlu mengembangkan berpikir kritis agar mahasiswa memiliki kemampuan bersikap dan berperilaku adaptif dalam menghadapi tantangan.

Peneliti mengunakan model think pair share sebagai usaha meningkatkan kemampuan berpikir kritis mahasiswa. Model TPS termasuk dalam model pembelajaran kooperatif di mana dalam proses pembelajaran mengaktifkan siswa dalam kegiatan diskusi. Pembelajaran dengan model TPS dibagi dalam 3 tahap yaitu Langkah 1: berpikir (thinking) Langkah 2: berpasangan (pairing), Langkah 3: berbagi (sharing)

Lie (2004: 57) keunggulan teknik think pair share adalah optimalisasi partisipasi siswa. Optimalisasi dalam partisipasi mahasiswa menjadi titik tolak keberhasilan think pair share dalam meningkatkan kemamopuan berpikir kritis.

Berdasarkan uraian di atas, dapat diketahui bahwa pembelajaran pada matakuliah pembelajaran terpadu perlu ditingkatkan, oleh karena itu peneliti melakukan penelitian efektivitas think pair share (TPS) untuk meningkatkan kemampuan berpikir kritis mahasiswa PGSD Undana).

\section{METODE}

Penelitian ini akan dilakukan di Kampus PGSD Universitas Nusa Cendana. Penelitian ini menggunakan penelitian eksperimen untuk kepentingan penelitian ini, sampel dipilih menggunakan teknik purposive sampling dengan pertimbangan bahwa jumlah mahasiswa dan tingkat kemampuan mahasiswa di kelas eksperimen dan kelas kontrol relatif sama. Berdasarkan teknik tersebut terpilihlah semester IV A dan semester IV E. Penelitian ini merupakan penelitian semu (quasi eksperiment). Penelitian ini menggunakn desain pretest-posttest control group design. Pretest dilakukan sebelum di berikan model TPS untuk mendapatkan data kemampuan awal kemampuan berpikir kritis mahasiswa. Posttest dilakukan setelah diberikan perlakuan untuk mendapatkan data kemampuan berpikir kritis.

Tes analisis data dimulai dengan memastikan valiiditas dan reliabilitas soal kemampuan berpikir kritis untuk selanjutnya akan dihitung keefektifan dari model think pair share untuk meningkatkan kemampuan berpikir kritis. Keefektifan yang dimaksud adalah ketepatan tujuan pembelajaran yang berupa penguasaan kompetensi siswa dalam pembelajaran dengan menggunakan bahan ajar. Untuk menguji keefektifan bahan ajar, dilakukan uji t untuk mengetahui ada perbedaan kemampuan berpikir kritis kelas ekperimen dan kelas kontrol, serta uji $\mathrm{N}$-gain untuk mengetahui adanya peningkatan hasil belajar siswa.

\section{HASIL DAN PEMBAHASAN}

Tahap awal penelitian melalui studi lapangan dan tes awal pada siswa kelas , diketahui bahwa perangkat pembelajaran yang digunakan sebagai panduan belajar, kurang melatih kemampuan berpikir kritis siswa. model think pair share lebih banyak mengarah pada hasil belajar saja tanpa memperhatikan proses kemampuan berpikir siswa. Cara belajar siswa sebagian cenderung hanya menghafal konsep yang sudah ada. Siswa terbiasa malas dan tidak terlatih berpikir. Hal ini diketahui dari hasil tes awal yang berupa soal uraian yang menunjukan bahwa siswa hanya dapat menjawab 
soal yang jawabannya ada di buku. Untuk menjawab soal yang lebih menantang, siswa kesulitan dan tidak dapat memberikan penjelasan lebih lanjut. Dari daftar nilai guru, juga menunjukan rata-rata nilai harian yang rendah tidak mencapai nilai Baik.

Berdasarkan temuan dan hasil studi literatur, model pembelajaran yang cocok untuk mahasiswa PGSD Universitas Nusa Cendana adalah model pembelajaran think pair share. Model pembelajaran ini mengadopsi dari pendekatan konstruktivisme. Untuk menilai hasil belajar, digunakan pedoman penilaian yang dilengkapi dengan indikator kemampuan berpikir kritis yang mengadopsi dari karya Ennis (1985).

Untuk mengetahui validitas instrumen soal ulangan harian, dilakukan uji validitas instrumen. Hasil uji validitas terhadap 20 soal ulangan harian yang diujicobakan pada kelompok kecil (uji skala terbatas) pada 47 mahasiswa PGSD disajikan tabel 1

Tabel 1 Hasil Validitas Instrumen Soal Uji Skala Kecil

\begin{tabular}{cccc}
\hline Jumlah Soal & Rata-rata r $_{\text {hitung }}$ & Rata-rata $\mathbf{r}_{\text {tabel }}$ & Keputusan \\
\hline 20 & 0,563 & 0,444 & Valid \\
\hline
\end{tabular}

Kriteria analisis, jika nilai $r_{\text {hitung }}>r_{\text {tabel, }}$ maka butir soal valid. Terlihat dari tabel di atas, seluruh butir soal $r_{\text {hitung }}>r_{\text {tabel }}$ sehingga seluruh butir soal valid dan dapat digunakan untuk penelitian.

Untuk mengetahui reliabilitas instrumen soal ulangan harian, dilakukan uji Reliabilitas instrumen. Hasil uji validitas terhadap 20 soal ulangan harian yang diujicobakan pada kelompok kecil (uji skala terbatas) pada 47 mahasiswa PGSD Universitas Nusa Cendana.

Tabel 2. Hasil Reliablitias Instrumen Soal Uji Skala Kecil Tabel reliabilitas

\section{Cronbach's Alpha Jumlah Soal}

0,665

20

Berdasarkan hasil uji reliabilitas instrumen tes ulangan harian dengan Alpha Cronbach dengan perhitungan SPSS 21 diperoleh nilai $r_{\text {hitung }}\left(r_{11}\right)=0,665$ nilai tersebut menunjukan bahwa koeffisien korelasi reliabilitas berada pada pada $0,60 \leq r_{11} \leq 0,80$ maka dikatakan bahwa instrumen soal memiliki reliabilitas tinggi.

Keefektifan think pair share yang dikembangkan dilakukan dengan uji $t$ untuk mengetahui ada perbedaan kelas kontrol dan kelas ekperimen serta uji $\mathrm{N}$-gain untuk mengetahui peningkatan pretest-posttest kelas eksperimen.

Setelah uji prasyarat, dapat dilakukan uji hipotesis untuk mengetahui kefektifan produk (perangkat pembelajaran dengan model think pair share dengan uji perbedaan dua rata-rata pretest antara kelompok eksperimen dan kelompok kontrol menggunakan SPSS 21 seperti disajikan pada tabel 3

\begin{tabular}{cccc}
\hline \multicolumn{4}{c}{ Tabel 3.Test of Homogeneity of Variances } \\
\hline $\begin{array}{c}\text { pretest kontrol } \\
\text { Levene Statistic }\end{array}$ & df1 & df2 & Sig. \\
\hline 0,059 & 1 & 92 & 0,808 \\
\hline
\end{tabular}

Pada uji homogenitas data nilai preetest kelompok eksperimen dan kontrol diperoleh nilai signifikan 0,808 > 0,05 maka Ho diterima atau kedua kelompok mempunyai varian yang sama (varian datanya homogen). Hal ini berarti kelompok eksperimen dan kelompok kontrol adalah kelas yang homogen. 
Tabel 4. One-Sample Kolmogorov-Smirnov Test

\begin{tabular}{cc}
\hline & Unstandardized Residual \\
\hline Asymp. Sig. (2-tailed) & 0,334 \\
\hline
\end{tabular}

Perolehan hasil uji normalitas data nilai pretest kelas kontrol dan eksperimen adalah signifikan hasil belajar 0,334 >0,05 menunjukan bahwa data berdistribusi normal

Tabel 5. Hasil Uji-t Pretest Kelas Eksperimen da Kontrol

\begin{tabular}{lr}
\hline & $\begin{array}{c}\text { Pretest kelas eksperimen- } \\
\text { pretest kelas control }\end{array}$ \\
\hline Z & $-0,572$ \\
Asymp. Sig. (2-tailed) & 0,139 \\
\hline
\end{tabular}

Nilai uji-t menunjukan bahwa nilai siginfikansi $0,139>0,05$ maka Ho diterima, artinya hipotesis yang menyatakan tidak ada perbedaan antara kelompok eksperimen dan kelompok kontrol diterima. Jadi disimpulkan bahwa sebelum diberikan perlakukan kedua kelompok memiliki kemampuan awal yang sama.

Tabel 6. Hasil Uji-t Posttest Kelas Eksperimen dan Kontrol

\begin{tabular}{lr}
\hline & Kelas eksperimen dan kelas kontrol \\
\hline A & $-3,129$ \\
Asymp. Sig. (2-tailed) & 0,000 \\
\hline
\end{tabular}

Berdasarkan tabel 4., terlihat bahwa nilai signifikansi $0,000<0,05$ maka Ho ditolak dan $\mathrm{Ha}$ diterima, artinya hipotesis yang menyatakan ada perbedaan antara kelompok eksperimen dan kelompok kontrol ditolak, yang berarti bahwa setelah diberi pembelajaran dengan model think pair share, ternyata perolehan nilai posttest (nilai hasil belajar) kelompok eksperimen lebih tinggi dari kelompok kontrol. Jadi disimpulkan bahwa ada perbedaan rata-rata nilai posttest antara kelompok eksperimen dengan kelompok kontrol. Dalam hal ini nilai rata-rata posttest kelompok eksperimen lebih baik daripada kelompok kontrol.

Untuk mengetahui keefktifan perangkat pembelajaran yang dikembangkan dapat dilihat dari perbandingan peningkatan hasil belajar tiap individu secara keseluruhan melalui perbandingan rata-rata peningkatan nilai pretest dan posttes antara kelas eksperimen dan kelas kontrol menggunakan uji N-gain.

Tabel 7. Perbandingan Rata-rata $\mathrm{N}$-gain

\begin{tabular}{cccccc}
\hline \multicolumn{3}{c}{ Kelompok Kontrol } & \multicolumn{3}{c}{ Kelompok Eksperimen } \\
\hline Pretest & Posttest & $\mathrm{N}$-gain & Pretest & Posttest & $\mathrm{N}$-gain \\
\hline 62,02 & 69,25 & 0,017 & 69,91 & 90,74 & 0,65 \\
\hline
\end{tabular}

Berdasarkan Tabel 51 dapat dilihat bahwa N-gain kelompok eksperimen 0,65 berada pada rentang $0,70>\mathrm{g}>0,30$ menunjukan kriteria sedang dan kelompok kontrol hanya 0,017 . Dengan demikian dapat disimpulkan bahwa penggunaan model think pair share secara keseluruhan efektif untuk meningkatkan hasil belajar siswa pada mata kuliah pembelajaran terpadu.

Kemampuan berpikir kritis merupakan kemampuan yang sangat esensial untuk kehidupan, pekerjaan, dan berfungsi efektif dalam semua akspek kehidupan lainnya. Berdasarkan pendapat Ngalimun (2014:69) bahwa critical thinking (berpikir kritis) adalah kegiatan berpikir yang dilakukan dengan mengoperasikan potensi intelektual untuk menganalisis, membuat pertimbangan dan mengambil keputusan secara tepat 
dan melaksanakannya secara benar. Proses tersebut merupakan bentuk berpikir yang perlu dikembangkan dalam memecahkan masalah, merumuskan kesimpulan dan membuat keputusan. Berpikir kritis juga merupakan bagian mengevaluasi mempertimbangkan kesimpulan yang akan diambil sebab berpikir langsung kepada fokus yang akan dituju.

Pencapaian indikator kemampuan berpikir kritis dalam penelitian ini ditelusuri bahwa jawaban soal uraian dituliskan mahasiswa. Dari hasil analsis peningkatan kemampuan berpikir kritis berdasrkan perolehan rata-rata $\mathrm{N}$-gain nilai pretest dan posttest untuk empat indikator kemampuan berpikir kritis yang meliputi trigger event, exploration, integration, dan resolution.

\section{SIMPULAN}

Berdasarkan kajian teori dan analisis hasil penelitian yang telah dikemukakan pada bab sebelumnya, maka dapat disimpulkan terdapat perbedaan kemampuan berpikir kritis pada pembelajaran menggunakan model think pair share untuk mahasiswa PGSD Universitas Nusa Cendana nilai signifikansi uji T 0,000 $>0,005$ yang berarti Ho ditolak dan Ha diterima. Hal ini berarti ada perbedaan antara kelas kontrol dan eksperimen. Dan terdapat peningkatan kemampuan berpikir kritis pada pembelajaran menggunakan model think pair share untuk mahasiswa PGSD Universitas Nusa Cendana dengan nilai n-gain pada kelas eksperimen mencapai 0,65 yang berarti berada pada $0,70>\mathrm{g}>0,30$ kriteria sedang.

\section{DAFTAR PUSTAKA}

Anni, T. C. (2009). Psikologi belajar. Semarang: UPT Unnes Press.

Arikunto, S.(2012). Dasar-Dasar Evaluasi Pendidikan. Jakarta: Bumi Aksara.

Asmani, Jamal Ma'mur. (2016). Tips Efektif Cooperative Learning. Yogyakarta:

DIVA Press.

Aunurrahman. (2009). Belajar dan Pembelajaran. Bandung: Alfabeta.

Borg \& Gall. (1983). Educational Research: an introduction. New York: Logman.

Djamarah, S.B. (2008). Psikologi Belajar. Jakarta: Rineka Cipta.

Fraenkel, Jack R \& Norman E. Wallen. (2009). How to Design and Evaluate

Research in Education 7th Edition. New York: McGraw-Hill.

Hamalik, Oemar. (2008). Kurikulum dan Pembelajaran. Jakarta: Bumi Aksara.

Hamdani. (2011). Strategi Belajar Mengajar. Bandung: Pustaka Setia.

Isjoni. (2010). Pembelajaran Kooperatif, Meningkatkan Kecerdasan Komunikasi

Antarpeserta Didik. Yogyakarta: Pustaka Pelajar.

Komara, E. (2014). Belajar dan Pembelajaran Interaktif. PT Refika Aditama. Bandung.

Lie, Anita. (2004). Cooperative Learning. Jakarta: Grasindo.

Ngalimun. (2014). Strategi dan Model Pembelajaran. Yogyakarta: Aswaja Presindo.

Prastowo, A. (2011). Panduan Kreatif Membuat Bahan Ajar Inovatif. Yogyakarta: Diva Press.

Plomp, T \& Nieveen, N. (2007). An Introduction to Educational Design Research. Netherland: Netzodruk,enschede.

Pribadi, B.A. (2009). Model Desain Sistem Pembelajaran. Jakarta: Dian Rakyat.

Poerwanti, E. Dkk. (2008).Asesmen Pembelajaran SD. Direktorat Jendral Pendidikan Tinggi: Depdiknas.

Putra, S.R. (2013). Desain Belajar Mengajar Kreatif Berbasis Sains. Jakarta Diva Press.

Sanjaya, W. (2006). Strategi Pembelajaran Berorientasi Standar Proses Pendidikan. Jakarta : Kencana.

Wena, M. (2014). Strategi Pembelajaran Inovatif kontemporer Suatu Tinjauan Konseptual Operasional. Jakarta: Bumi Aksara. 